\title{
Behavioral parameters evaluation after homeopathic Zincum metallicum treatment: a transgenerational study in mice
}

\author{
Silvio Leite Monteiro da Silva1; Cideli de Paula Coelho ${ }^{2,3}$; \\ Luana de Ramos Soares²; Amarilys de Toledo Cesar", \\ Maria Martha Bernardi ${ }^{3}$; Carla Holandino Quaresma ${ }^{5}$, \\ Paolo Bellavite ${ }^{6}$, Leoni Villano Bonamin ${ }^{3}$
}

(1) IF Sudeste MG campus Rio Pomba, Minas Gerais, Brazil; (2) Research Center, Universidade Paulista (UNIP), São Paulo, Brazil;

(3) Universidade de Santo Amaro, São Paulo, Brazil;

(4) H\&N Homeopatia-Farmácias HNCristiano;

(5) Universidade Federal do Rio de Janeiro, Rio de Janeiro, Brazil;

(6) Universita' degli studi di Verona, Verona, Italy

Zincum metallicum $(Z M)$ is a homeopathic medicine whose material medica is defined by diverse behavioral and mental symptoms, including depression. Moreover, as a microelement, zinc itself is involved in several functions of Central Nervous System, including development and cell maturity during the intra-uterus life. Herein, the putative transgenerational effects of different homeopathic potencies of ZM upon behavioral parameters in P and F1 generations were evaluated. Since mice and the tail suspension test (TST) are references for evaluating antidepressant agent activity, the TST together with the open field test (OPT) and the elevated plus maze test (EPM) were used to analyze offspring behavioral parameters. All animal procedures were in agreement with the Brazilian ethical research practices and were approved by the institutional ethical committee (CEUA-UNIP) under the protocol 156/2013. Four groups of seven females Balb/C mice were exposed to $0,1 \mathrm{~mL}$ of $\mathrm{ZM} 5 \mathrm{cH}, 30 \mathrm{cH}, 200 \mathrm{cH}$ and lactose $5 \mathrm{cH}$, diluted in $250 \mathrm{~mL}$ of drinking water, during pregnancy and post partum period, in a total of 31 days. The flasks were coded before the remedies administration and all experimental procedures, including statistical analysis were done in blind. The parents were previously distributed in a Completely Randomized Design for the mates, according to the TST previous results. Mothers were re-evaluated for TST after weaning and mice of F1 generation were evaluated for TST, EPM and OPT when they reached two months old. According to the time of immobilization in TST, animals were classified as healthy (h), intermediate (i) and depressed (d) $(<116 ; 117-180$ and $>180$ seconds of immobilization, respectively). No significant changes were seen among the groups regarding to the number of newborns, sex proportions, TST, OPT and EPM behavioral parameters, besides the fact that the treatment with ZM $200 \mathrm{cH}$ was associated to the majority of healthy F1 mice (male: $\mathrm{n}=8$ : $7 \mathrm{~h}+1 \mathrm{i}+0 \mathrm{~d}$; female: $\mathrm{n}=8: 8 \mathrm{~h}+0 \mathrm{i}+0 \mathrm{~d}$ ), in relation to the number of delivery per group (Fisher test, $\mathrm{p} \leq 0.01$ ). Treatment with $\mathrm{ZM}$ $5 \mathrm{cH}$, instead, produced reduced number of pups with no male mouse among $\mathrm{F} 1$ generation. We conclude that the treatment of pregnant females with $\mathrm{ZM} 200 \mathrm{cH}$ produced the best results in $\mathrm{F} 1$ generation regarding reproduction and behavioral parameters and the treatment with $\mathrm{ZM} 5 \mathrm{cH}$ reduced births in relation to control. The involved mechanisms have to be elucidated in the next steps of the study. 
Keywords: UHD, Depression-anxiety behavior, transgenerational mice.

\section{(c)) EY-NC-ND Licensed to GIRI}

Support: Coordination for the Improvement of Higher Education Personnel (CAPES) PROSUP\#1187970 for doctorate allowance; H\&N Homeopatia-Farmácias HNCristiano e Farmácia Universitária da Universidade Federal do Rio de Janeiro for general support.

Conflict of interest: authors declare there is no conflict of interest

Received: March 30th 2014; Revised: May 10 th 2014; Published: June 30 2014.

Correspondence author: Silvio Leite Monteiro da Silva, silvio.leite@ifsudestemg.edu.br

How to cite this article: Monteiro da Silva SL; Coelho CP; Soares LR; Bernardi MM; Bonamin LV. Behavioral parameters evaluation after homeopathic zincum metallicum treatment: a transgeneration study in mice. Int J High Dilution Res [online]. 2014 [cited YYYY Month dd]; 13(47):137-138. Proceedings of the XXVIII GIRI Symposium; 2014 Jun20-22; Sighisoara (Romania). GIRI; 2014; Available from: http://www.feg.unesp.br/ ojs/index.php/ijhdr/article/view/741/718 